\title{
No association between vitamin D status and COVID-19 infection in São Paulo, Brazil
}

Cynthia M. Álvares Brandão'

Maria Izabel Chiamolera'

https:///rcid. org/0000-0002-9606-2841

Rosa Paula Mello Biscolla ${ }^{1}$

https://orcid. org/0000-0003-4358-6622

José Viana Lima Junior ${ }^{1}$

https://orcid. org/0000-0003-3922-4215

Cláudia M. De Francischi Ferrer ${ }^{1}$

https://orcid.org/0000-0002-1045-6058

Wesley Heleno Prieto'

https://orcid. org/0000-0003-4715-9345

Pedro de Sá Tavares Russo'

https://orcid. org/0000-0002-4615-7498

José de Sá

https://orcid.org/0000-0003-4117-4958

Carolina dos Santos Lazari ${ }^{1}$

https://orcid. org/0000-0002-1418-1880

Celso Francisco H. Granato'

https://orcid.org/0000-0003-2820-3005

José Gilberto H Vieira'

https://orcid. org/0000-0002-7121-4458

\begin{abstract}
In recent years the immunomodulatory actions of vitamin $D$, a steroid hormone, have been extensively studied. In 2020, due to the COVID-19 pandemic, the question arose as to 25(OH)D status would be related to susceptibility to SARS-CoV-2 infection, since several studies pointed out a higher prevalence and severity of the disease in populations with low levels of 25(OH)D. Thus, we investigated the $25(\mathrm{OH}) \mathrm{D}$ levels in adults "Detected" positive for SARS CoV-2 by RT-PCR (reverse transcriptase polymerase chain reaction) test, and in negative controls, "not Detected", using the Fleury Group's examination database, in Sao Paulo, Brazil. Of a total of 14.692 people with recent assessments of 25(OH)D and RT-PCR tests for COVID-19, 2.345 were positive and 11.585 were negative for the infection. The groups did not differ in the percentage of men and women, or in the age distribution. There were no differences in the distribution of $25(\mathrm{OH}) \mathrm{D}$ between the two groups $(p=0.08)$; mean $25(\mathrm{OH}) \mathrm{D}$ of $28.8 \pm 21.4 \mathrm{ng} / \mathrm{mL}$ and $29.6 \pm 18.1 \mathrm{ng} / \mathrm{mL}$, respectively. In the specific population studied, clinical, environmental, socioeconomic and cultural factors should have greater relevance than $25(\mathrm{OH}) \mathrm{D}$ in determining the susceptibility to COVID-19. Arch Endocrinol Metab. 2021;65(3):381-5
\end{abstract}

Keywords

Vitamin D; coronavirus; COVID-19
Correspondence to:

Cynthia M. Álvares Brandão

Rua Mato Grosso, 306, cj. 408

01239-040 - São Paulo, SP, Brasil

cynthiabrandao@uol.com.br

Received on June/6/2020 Accepted on Feb/16/2021

DOI: $10.20945 / 2359-3997000000343$

\section{INTRODUCTION}

$\mathrm{T}$ The musculoskeletal effects of vitamin D are widely studied, as well as its endocrine actions in regulating the homeostasis of calcium and phosphorus. Cholecalciferol or "vitamin D", synthesized in the skin, is metabolized in the liver to 25 -hydroxycholecalciferol $(25(\mathrm{OH}) \mathrm{D})$ and then in the kidney to its biologically active form, 1,25-dihydroxycholecalciferol (1,25(OH)2D). The metabolite $25(\mathrm{OH}) \mathrm{D}$ is the major circulating form of vitamin D in humans, and it is used to reflect person's vitamin $\mathrm{D}$ status.

Vitamin D deficiency causes secondary hyperparathyroidism, osteomalacia, osteopenia and an increased risk of fractures. In addition to its classic 
functions in osteomineral metabolism, the extensive distribution of vitamin $\mathrm{D}$ (VDR) receptors in human tissues and the action of the active hormone, $1,25(\mathrm{OH}) 2 \mathrm{D}$ (calcitriol), in regulating the transcription and expression of countless genes, indicate the importance of nonskeletal actions of this hormone. Experimental and clinical studies have revealed the intracrine action of vitamin D in the immune system, particularly in monocytes and macrophages, with a modulating role for both innate and adaptive immune responses against a number of microorganisms, including viruses $(1,2)$.

Autophagic encapsulation of viral particles is also a cellular process enhanced by both $25(\mathrm{OH}) \mathrm{D}$ and $1,25(\mathrm{OH}) 2 \mathrm{D}(3)$, with a fundamental role in reducing viralinfectivity, for example for humanimmunodeficiency virus type 1 (4). In addition, other data revealed a role of vitamin $\mathrm{D}$ in pulmonary protection against acute respiratory infections, in particular its action on capillary permeability, which plays a fundamental role in the pathophysiology of many diseases with pulmonary involvement $(5,6)$. Respiratory epithelial cells constitutively express $1 \alpha$-hydroxylase resulting in local activation of vitamin D. Vitamin D-dependent genes including cathelicidin and CDI4 are upregulated after the exposure of airway epithelial cells to the inactive vitamin $\mathrm{D}$ precursor (7).

In 2020, during the coronavirus disease (COVID-19) pandemic, several retrospective studies were published, showing an association between low $25(\mathrm{OH}) \mathrm{D}$ status and increased susceptibility to and severity of SARS-CoV-2 infection, suggesting a deleterious effect of hypovitaminosis $\mathrm{D}$ on the incidence and clinical evolution of COVID-19 (8-12). Experimental research has shown that $1,25(\mathrm{OH}) 2 \mathrm{D}$ modulates the expression of angiotensin-converting enzyme 2, which is the receptor for the entry of SARS CoV-2 into cells. VDR-null mice showed more severe acute lung injury in a sepsis model than their wildtype counterparts (13). Thus, it became essential to study the relationship between $25(\mathrm{OH}) \mathrm{D}$ and SARS $\mathrm{CoV}-2$ incidence, with the aim of identifying an easily modifiable factor that can play a preventive role in all populations susceptible to infection.

\section{OBJECTIVE}

To compare $25(\mathrm{OH}) \mathrm{D}$ levels between individuals infected with SARS-CoV-2, with diagnostic confirmation by RT-PCR (reverse-transcriptase polymerase chain reaction), and individuals negative for SARS-CoV-2, using the Fleury Group's database.

\section{SUBJECTS AND METHODS}

\section{Data source}

Fleury Group is a medical organization that provides supplemental health services in Brazil. Data were collected from the Fleury Group's Caché database, of 14692 individuals who underwent RT-PCR tests for the diagnosis of COVID-19, from March to July 2020, who also had $25(\mathrm{OH}) \mathrm{D}$ measured; participants were identified by a unique register number. The study protocol was approved by the research and ethics committee of Fleury Group (protocol number 4.409.445, CAAE 39961120.7.00005474). Informed consent was not required since the data were anonymized.

\section{Study design}

This was a retrospective study that collected records from individuals of both genders, between 18 and 90 years old, with RT-PCR results for SARS CoV-2 and who simultaneously had their $25(\mathrm{OH}) \mathrm{D}$ measured over a period of 30 days before or after the collection of the sample for COVID-19 RT-PCR test. In cases of patients with more than one vitamin $\mathrm{D}$ test, the most recent in relation to the RT-PCR date, was selected. Records with 25(OH)D above $100 \mathrm{ng} / \mathrm{mL}$ were excluded to avoid distortions in the analysis of vitamin $\mathrm{D}$ averages. After removing entries with missing data and inconclusive diagnostic tests for COVID-19, the new dataset $(\mathrm{n}=13930)$ was divided into two groups: "Detected" or positive for COVID-19 (2345 patients) and "Not Detected" or negative for COVID-19 (11585 patients).

\section{Biochemical analysis}

$25 \mathrm{OH}$ vitamin D - Liason, CLIA, DiaSorin, Saluggia, Italy, reference range: $20-60 \mathrm{ng} / \mathrm{mL}$, intra and interassay coefficient of variation are $6.0 \%$ and $8.0 \%$, respectively; RT-PCR - molecular test developed entirely in house according to the Charité protocol and a confirmatory test by the CDC protocol when necessary for confirmation, using clinical samples from the respiratory tract. 


\section{Statistical analysis}

To assess the significant differences between the groups, the normality of the two groups was confirmed (Kolmogorov-Smirnov Normality Test) and then, the difference between the means of the groups was verified using the Welch T test (Software R, www.r-project.org). This is a parametric test, adapted from the Student's t-test, whose objective is to compare two independent groups, without the hypothesis of equal population variance. The test considers the difference between the number of patients in each group when calculating the real difference between the means (14). Statistical significance was defined as $\mathrm{p}<0,05$.

\section{RESULTS}

There was no difference between groups regarding the percentage of men and women, or regarding the age distribution. There was no significant difference for the mean $25(\mathrm{OH}) \mathrm{D}$ between men and women, or between adults and the elderly (over 60 years), (multiple T tests with Bonferroni correction). The Detected Group had a mean $25(\mathrm{OH}) \mathrm{D}$ of $28.8 \pm 21.4 \mathrm{ng} / \mathrm{mL}$, with a median of $26.0 \mathrm{ng} / \mathrm{mL}$. The not Detected Group had a mean $25(\mathrm{OH}) \mathrm{D}$ of $29.6 \pm 18.1 \mathrm{ng} / \mathrm{mL}$, with a median of $27.0 \mathrm{ng} / \mathrm{mL}$. Table 1 shows the percentage of individuals and the means of $25(\mathrm{OH}) \mathrm{D}$, separated by the ranges of the values, $<12 \mathrm{ng} / \mathrm{mL}, 12-20 \mathrm{ng} / \mathrm{mL}$, 20-30 ng/mL and > $30 \mathrm{ng} / \mathrm{mL}$, in both Detected and not Detected groups $(15,16)$.

There was no difference in the distribution of $25(\mathrm{OH}) \mathrm{D}$ between the "Detected" and "not Detected" groups $(\mathrm{p}=0.081 \mathrm{l})$. Figure 1 shows the dispersion of the values of $25(\mathrm{OH}) \mathrm{D}$ between the Detected and not Detected groups.

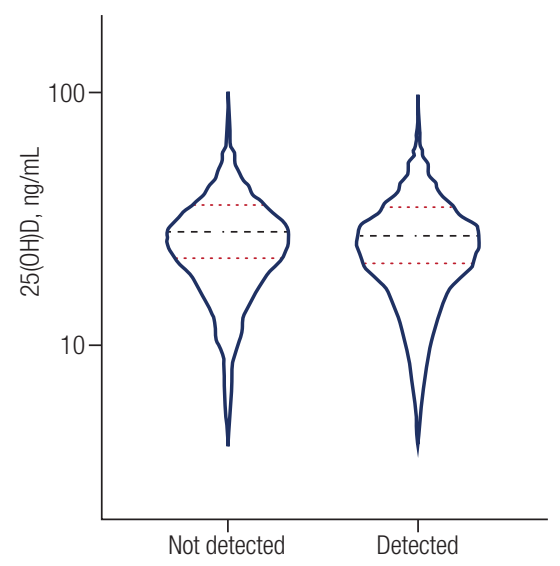

Figure 1. The image shows the dispersion of $25(\mathrm{OH}) \mathrm{D}$, in patients Detected and Not Detected for COVID-19; means are indicated by the black line and two standard deviations (SD) by the red line.

\section{DISCUSSION AND CONCLUSIONS}

Studies prior to the COVID-19 pandemic period have demonstrated the role of vitamin $\mathrm{D}$ in innate and adaptive immunity, particularly in protection against viral and bacterial infections. Martineau et al demonstrated, in a large meta-analysis of randomized controlled trials, that vitamin D supplementation reduced the risk of experiencing at least one acute respiratory tract infection (17). The initial spread of COVID-19 occurred in countries that were going through the winter, had a high prevalence of hypovitaminosis $\mathrm{D}$. Together, these data raised the question of the role of vitamin $\mathrm{D}$ to susceptibility and the severity of the disease.

Numerous studies initially linked $25(\mathrm{OH}) \mathrm{D}$ status to susceptibility and mortality from SARS-CoV-2, although causality cannot be demonstrated (8-12). The clinical evolution and severity of COVID-19 respiratory

Table 1. Number of patients, mean and percentage of patients by ranges of $25(\mathrm{OH}) \mathrm{D}$, for the "Detected" and "not Detected" groups. Multiple $\mathrm{T}$ tests with Bonferroni correction were applied; t-test were performed using the log-transformed values of the means

\begin{tabular}{|c|c|c|c|c|c|c|c|c|c|}
\hline 25(OH)D & Group & n & $\%$ & $\begin{array}{c}\text { Means } \\
25(\mathrm{OH}) \mathrm{D} \\
\mathrm{ng} / \mathrm{mL}\end{array}$ & Group & n & $\%$ & $\begin{array}{c}\text { Means } \\
\text { 25(OH)D } \\
\mathrm{ng} / \mathrm{mL}\end{array}$ & $p$ value \\
\hline$<12 \mathrm{ng} / \mathrm{mL}$ & Detected & 137 & 5.84 & 8.68 & Not detected & 579 & 5.0 & 9.01 & 0.10 \\
\hline $12-20 \mathrm{ng} / \mathrm{mL}$ & Detected & 448 & 19.1 & 15.83 & Not detected & 2066 & 17.8 & 16.08 & 0.13 \\
\hline 20-30 ng/mL & Detected & 911 & 38.8 & 24.51 & Not detected & 4306 & 37.2 & 24.6 & 0.42 \\
\hline > $30 \mathrm{ng} / \mathrm{mL}$ & Detected & 849 & 36.2 & 43.4 & Not detected & 4634 & 40.0 & 42.84 & 0.73 \\
\hline
\end{tabular}


disease has enormous complexity and competition from numerous other confounding factors, such as obesity, hypertension, socioeconomic level, quality of medical care, comorbidities and probably, the degree of exposure and genetic susceptibility. However, individuals with inadequate $25(\mathrm{OH}) \mathrm{D}$ could have an additional risk of contracting a viral infection such as COVID-19, and possibly a greater risk of an unfavorable clinical course $(3,6,18)$. Additionally the social isolation, imposed to control the pandemic, could be a predisposing factor to less sun exposure.

However, our study showed no difference in $25(\mathrm{OH}) \mathrm{D}$ status in a large group of Brazilian infected individuals with SARS CoV-2 and non infected controls. The same conclusion was reached by Hastie and cols. (19) and Raisi-Estabragh and cols. (20), using UK Biobank data. Neither study supports the hypothesis of a link between vitamin D levels and the risk of SARS CoV-2 infection, nor does $25(\mathrm{OH}) \mathrm{D}$ explain the ethnic differences in COVID-19 prevalence.

The population sample evaluated in this study has a high socioeconomic level, has access to private medical services, and is predominantly of Caucasian origin; therefore, we were unable to assess socioeconomic or ethnic-racial factors that could affect infectivity. Another aspect to be considered is that the pandemic spread in Brazil during late summer and early fall, periods characterized by higher levels of solar irradiation; therefore, low $25(\mathrm{OH}) \mathrm{D}$ is less prevalent. Unfortunately, we were also unable to control for other clinical risk parameters for COVID-19, such as weight, diabetes and other comorbidities.

Despite all of the evidence described in the literature on the immunological action of vitamin $\mathrm{D}$, we did not observe differences between 25(OH)D status and COVID-19 susceptibility in a large Brazilian population sample. The strength of this study is the number of participants, mostly Sao Paulo residents, the largest city in Brazil located in the southeastern region of the country. The study population, both with and without SARS CoV-2 infection, has a lower prevalence of hypovitaminosis $\mathrm{D}$, compared to that described in the European or American populations, or even within specific population subgroups living in Sao Paulo, such as the elderly over 80 , institutionalized or chronically ill patients (16).

In conclusion, clinical, environmental, socioeconomic and cultural factors have greater relevance than vitamin D status in determining the susceptibility to SARS-CoV-2 infections in the population studied.
Contributors: all the authors contributed to the manuscript.

Financial support: Fleury Group Research and Development Center funded study statistical analysis.

Disclosure: no potential conflict of interest relevant to this article was reported.

\section{REFERENCES}

1. Charoenngam N, Holick M. Immunologic effects of vitamin D on human health and disease. Nutrients. 2020;12:2097.

2. Bouillon R, Marcocci C, Carmeliet G, Bikle D, White JH, DawsonHughes B, et al. Skeletal and Extraskeletal Actions of Vitamin D: Current Evidence and Outstanding Questions. Endocr Rev. 2019;40(4):1109-51.

3. Bilezikian JP, Bikle D, Hewison M, Lazaretti-Castro M, Formenti AM, Gupta A, et al. Mechanisms in Endocrinology: Vitamin D and COVID-19. European J Endocrinol. 2020;183(5):R133-R147.

4. Campbell GR, Spector SA. Toll-like receptor 8 ligands activate a vitamin $D$ mediated autophagic response that inhibits human immunodeficiency virus type 1. PLoS Pathog. 2012;8(11):e1003017.

5. Ginde AA, Mansbach JM, Camargo CA. Association between Serum 25-hydroxyvitamin D level and upper respiratory tract infection in the Third National Health and Nutrition Examination Survey. Arch Intern Med. 2009;169(4):384-90.

6. Santos RND, Maeda SS, Jardim JR, Lazaretti-Castro M. Reasons to avoid vitamin D deficiency during COVID-19 pandemic. Arch Endocrinol Metab. 2020 Aug 28:S2359-39972020005006214. doi: 10.20945/2359-3997000000291.

7. Hansdottir S, Monick MM, Hinde SL, Lovan N, Look DC, Hunninghake GW. Respiratory epithelial cells convert inactive vitamin $D$ to its active form: potential effects on host defense. J Immunol. 2008;181(10):7090-9.

8. D’Avolio A, Avataneo V, Manca A, Cusato J, De Nicolò A, Lucchini R, Keller F, Cantù M. 25-Hydroxyvitamin D Concentrations Are Lower in Patients with Positive PCR for SARS-CoV-2. Nutrients. 2020;12(5):1359.

9. Merzon E, Tworowski D, Gorohovski A, Vinker S, Golan Cohen A, Green I, Frenkel-Morgenstern M. Low plasma $25(\mathrm{OH})$ vitamin D level is associated with increased risk of COVID-19 infection: an Israeli population-based study. FEBS J. 2020;287(17):3693-3702. doi: 10.1111/febs.15495.

10. Ilie PC, Stefanescu S, Smith L. The role of vitamin D in the prevention of coronavirus disease 2019 infection and mortality. Aging Clin Exp Res. 2020 Jul;32(7):1195-8.

11. Meltzer DO, Best TJ, Zhang H, Vokes T, Arora V, Solway J. Association of Vitamin D Status and Other Clinical Characteristics With COVID-19Test Results. JAMA Netw Open. 2020;3(9):e2019722.

12. Faul JL, Kerley CP, Love B, O'Neill E, Cody C, TormeyW, Hutchinson K, Cormican LJ, Burke CM. Vitamin D Deficiency and ARDS after SARS-CoV-2 Infection. Ir Med J. 2020;113(5):84.

13. Kong J, Zhu X, Shi Y, Liu T, Chen Y, Bhan I, Zhao Q, Thadhani R, Li YC. VDR attenuates acute lung injury by blocking Ang-2Tie-2 pathway and renin-angiotensin system. Mol Endocrinol. 2013;27(12):2116-25.

14. Derrick B, Toher D, White P. Why Welchs test is Type I error robust. Tutor Quant Methods Psychol. 2016;12(1):30-8.

15. Holick MF, Binkley NC, Bischoff-Ferrari HA, Gordon CM, Hanley DA, Heaney RP, et al. Evaluation, treatment, and prevention of vitamin D deficiency: an Endocrine Society clinical practice guideline. J Clin Endocrinol Metab 2011;96(7):1911-30. 
16. Moreira CA, Ferreira CEDS, Madeira M, Silva BCC, Maeda SS, Batista MC, et al. Reference values of 25-hydroxyvitamin D revisited: a position statement from the Brazilian Society of Endocrinology and Metabolism (SBEM) and the Brazilian Society of Clinical Pathology/Laboratory Medicine (SBPC). Arch Endocrinol Metab. 2020;64(4):462-78.

17. Martineau AR, Jolliffe DA, Hooper RL, Greenberg L, Aloia JF, Bergman $\mathrm{P}$, et al. Vitamin $\mathrm{D}$ supplementation to prevent acute respiratory tract infections: systematic review and meta-analysis of individual participant data. BMJ. 2017;356:i6583.
18. Biesalski HK. Vitamin D deficiency and co-morbidities in COVID-19 patients - A fatal relationship? NFS Journal. 2020;20:10-21.

19. Hastie CE, Mackay DF, Ho F, Celis-Morales CA, Katikireddi SV, Niedzwiedz CL, et al. Vitamin D concentrations and COVID-19 infection in UK Biobank. Diabetes Metab Syndr. 2020;14(4):561-5.

20. Raisi-Estabragh Z, McCracken C, Bethell MS, Cooper J, Cooper C, Caulfield MJ, et al. Greater risk of severe COVID-19 in Black, Asian and Minority Ethnic populations is not explained by cardiometabolic, socioeconomic or behavioural factors, or by $25(\mathrm{OH})$-vitamin D status: study of 1326 cases from the UK Biobank. J Public Health (Oxf). 2020;42(3):451-60. 